ISSN 0103-5150

Fisioter. Mov., Curitiba, v. 29, n. 1, p. 159-72, Jan./Mar. 2016

Licenciado sob uma Licença Creative Commons

DOI: http://dx.doi.org.10.1590/0103-5150.029.001.AR01

\title{
Whole-body vibration and musculoskeletal diseases in professional truck drivers
}

\author{
Vibração de corpo inteiro e desordens \\ musculoesqueléticas em motoristas de caminhão
}

\section{Geraldo Fabiano de Souza Moraes ${ }^{[a, b]}$, Rosana Ferreira Sampaio ${ }^{[a]}$, Luiz Felipe Silva ${ }^{[b]}$, Mariana Angélica Peixoto Souza ${ }^{[a] *}$}

[a] Universidade Federal de Minas Gerais, (UFMG), Belo Horizonte, MG, Brazil

[b] Universidade Federal de Itajubá, (UNIFEI), Itabira, MG, Brazil

\begin{abstract}
Background: Most occupational diseases do not fit the paradigm of medical interpretation of the health-disease process based on linear causality, in which it would be possible to find a single cause for each type of disease. Objectives: to conduct a systematic review in order to investigate the association between wholebody vibration (WBV) and musculoskeletal disorders (MSD) in professional truck drivers (PTD). Methods: The scientific databases of PubMed, Cochrane, Lilacs and Scielo were used to collect articles published from 2000 until the present time. Two independent reviewers adopted inclusion and quality criteria to evaluate the selected articles. Results: From adopted inclusion and quality criteria, nine articles were chosen to identify the association between MSD and WBV in PTD. The results showed that MSD seems to be closely associated to exposure to WBV in these workers, mainly due to high prevalence and symptoms of low back pain. Two cohort studies showed exposure to WBV as risk for MSD. Only one, with case-control design, did not show WBV as a
\end{abstract}

* GFSM: PhD, e-mail: geraldomoraes@unifei.edu.br RFS: PhD, e-mail: sampaioufmg@gmail.com LFS: PhD, e-mail: Llfelipe.unifei@gmail.com MAPS: MSc, e-mail: nanapsouza@yahoo.com.br 
significant factor. Conclusions: In this study the importance of exposure analysis of WBV in the occurrence of MSD in PTD was elucidated. This study showed the importance of WBV exposure analysis on the occurrence of MSD in PTD. There is adequate information to provide rationale for the reduction of WBV exposure to the lowest possible level, to ensure the health of these workers. Studies with a greater power of investigation, of a prospective, design, should be encouraged, supplanting those only of association.

Keywords: Vibration. Occupational hazard. Musculoskeletal diseases. Low back pain. Systematic review.

\section{Resumo}

Introdução: A maioria das doenças ocupacionais não se enquadra no paradigma médico de interpretação do processo saúde-doença baseado na causalidade linear, em que seria possível encontrar uma causa única para cada tipo de doença. Objetivo: Empreender uma revisão sistemática para investigar a associação entre vibração de corpo inteiro (VCI) e desordens musculoesqueléticas (MED) em motoristas profissionais de caminhão (PTD).

Métodos: Foram utilizadas as bases de dados científicas PubMed, Cochrane, LILACS e SciELO para coletar os artigos considerando publicações de 2000 aos dias atuais. Foram aplicados critérios de inclusão e avaliação da qualidade metodológica dos artigos selecionados por dois revisores independentes. Resultados: Nove artigos foram incluídos para identificar análises de associação entre VCI e MED em PTD. Os resultados demonstram que as MED parecem estar intimamente associadas à exposição à VCI nesses trabalhadores, principalmente devido à alta prevalência de dor lombar e sintomas decorrentes dessa afeç̧ão. Dois estudos de coorte apontaram a exposição à VCI como risco para MED. Somente um, com desenho caso - controle, não observou a exposição à VCI como significante. Conclusões: Este estudo elucidou a importância da análise da exposição à VCI na ocorrência de MED em PTD. Há informação adequada para dar razão à redução da exposição à VCI ao nível mais baixo possível, para assegurar as condições de saúde desses trabalhadores. Estudos com maior poder de investigação, como os prospectivos, devem ser estimulados, superando aqueles apenas de associação.

Palavras-chave: Vibração. Risco ocupacional. Doenças musculares. Dor lombar. Revisão sistemática.

\section{Background}

The labor world has undergone major changes in its organization and dynamics, creating new challenges and preserving unresolved problems on the health-labor relationship $(1,2)$.

Musculoskeletal disorders (MSD) are among those occupational diseases that currently demand attention in the health and labor area. These MSD have been highlighted in the agenda for discussion due to their high prevalence in all countries, regardless of the degree of industrialization (3-5). The MSD are followed by suffering and disability for workers and their families, and also result in social and financial losses, resulting from the decrease of productivity and deprivation of earnings, volume of granted benefits, medical expenses and integration of the individual in the production context $(6,7)$.

Epidemiological studies have shown that back pain accounts for approximately $50 \%$ of all MSD that cause temporary or permanent disability in workers in agricultural and industrial areas, and in service production. In addition, approximately $80 \%$ of the population have had, or will present with, an episode of pain back during his/her lifetime (7-9). Multiple risk factors are associated with the development of MSD in different sectors and occupations $(2-5,8)$. Individuals who perform work activities with a high demand of physical, cognitive and psychological features - as portrayed in the case of professional truck drivers (PTD) - are more susceptible to triggers of MSD. Physical demands, awkward postures and repetitive operations, as well as psychosocial loads, showed strong association with MSD in the lower back and even with involvement of the upper limbs, in some cases (9-11). In addition, personal attributes and characteristics of the productive context have also been identified as factors related to worsening of MSD, and therefore should be investigated in order 
to identify the correct ratio of its occurrence in PTD in their workplace $(6,7,12,13)$.

In recent years, studies conducted in the cargo transport sector have analyzed the exposure to whole-body vibration (WBV) and MSD occurrence, especially in the onset of low back pain in PTD and other machinery and vehicle operators, with direct harm to the development of these professionals' activities $(11,14)$. The impact of vibration on physical and technical capacity of the drivers may be related to the exposure time, intensity and frequency, as well as the operational and environmental conditions in which the activity is developed $(11,15)$. Evidence suggests that WBV exposure time triggers micro and macro impacts in the spine, and presents a clear relationship between the driver's position and the impact of transmission to important areas in the musculoskeletal system that directly compromises the absorption and dissipation of forces $(11,16$ - 18).

Despite advances in research in this area, there is no consensus when it comes to evidence that predicts the health risk to PTD on micro and macro impacts due to WBV exposure associated with the operation of cargo transport vehicles. In the same way, measures capable of minimizing the harmful effects of the MSD on the health of drivers remain uncertain. Given the above, this study aimed to conduct a systematic review to identify evidence that explores the significance of WBV exposure in the generation of MSD in PTD. We also aimed to summarize the evidence found regarding the theme, by assessing the methodological quality of these studies in order to clarify the involved factors in this relationship and to assist with proposals for prevention and health promotion of these workers.

\section{Methods}

A systematic review was conducted based on surveys of studies published between 2000 and 2014, in the databases of PubMed ${ }^{1}$, Cochrane ${ }^{2}$, LILACS $^{3}$ e $\mathrm{SciELO}^{4}$. This study period is justified due to the fact that the previous two systematic reviews on the subject were published in 1999 and 2000 with literature published from 1986 to 1997, (19) and from 1992 to 1999 (20), respectively. In this study, the last survey was performed in July of 2014. The keywords followed the description of the medical terms in English: 'Vibration' (MeSH), 'Whole Body Vibration', 'Musculoskeletal Disorder', 'Low Back Pain' (MeSH), 'Work' (MeSH), 'Workload' (MeSH), 'Occupational risk', 'Occupational Disease' (MeSH), 'Occupational Health' (MeSH), 'Occupational Accident' (MeSH), 'Occupational Hazard' and 'Truck Drivers'. Also, a search with the same keywords in Portuguese and Spanish was performed. Initially, keywords were crossed by using the Boolean operators "OR" and "AND", and then the active search for articles was performed.

In the present study, we included full-text articles with cross-sectional, case-control and cohort designs, as identified by the search strategy. Reviews and case reports were excluded. The studies should have presented an association between WBV and MSD in PTD.

We excluded studies that described the relationship between WBV and lower back pain in other occupations, and also studies with measurements that were performed in laboratories, studies using animals, experimental studies focused on interventions in the workplace, rehabilitation treatments and professional reintegration. Studies were selected by title, abstract and full text.

The summary of the identified articles after the application of the search strategy was evaluated by two independent examiners according to the following eligibility criteria: i) published in English, Portuguese or Spanish; ii) describe WBV assessment procedures with the use of a validated questionnaire/ scale; iii) consider MSD in PTD as an outcome; and iv) measure of WBV exposure in real work situations.

A standardized list of pre-defined criteria was used for evaluation of internal and external validity

\footnotetext{
1 PubMed: the bibliographic database [Internet]. Bethesda: National Library of Medicine; [s.d.]. Available at: http://www.ncbi.nlm. nih.gov/pubmed

2 Cochrane Library: Latin American and Caribbean Center of Information in Health Sciences. Bireme - PAHO - OMS. Available at: http://cochrane.bireme.br/portal/php/index.php

3 LILACS: Latin American and Caribbean Health Sciences Literature [Internet]. São Paulo: Bireme; [s.d.]. Available at: http://lilacs. bvsalud.org/

4 Scielo: Scientific Electronic Library Online. FAPESP - Bireme. São Paulo SP - Brazil. Available at: http://www.scielo.br/?lng=pt
} 
of the studies. The list was adapted from van der Windt et al. (21) and Hayden, Bombardier and Côté (22) (Table 1). Two independent reviewers applied the criteria, and their results were compared to select the potential articles for inclusion in this review. Discrepancies in the evaluation of the reviewers were discussed collectively to reach a consensus for a final decision about the inclusion or exclusion of the article.

The items of the assessment tool received the following classification: positive (no bias); negative (potential bias); undefined (when the information in the article was insufficient) and, lastly, do not apply. Disagreements between reviewers in certain items were identified and resolved during a consensus meeting. After reading the articles selected, the references cited therein were checked, and those judged relevant were also reviewed. Articles that met the study eligibility criteria were classified as ACCEPTED for this review and a full reading was performed.

For each study, a total quality index was calculated by counting the number of items classified as positive, divided by the total number of applicable study items.
Based on this final score, each item was classified as being of high or low quality. High quality studies were considered those in which at least $51 \%$ of applicable items were evaluated as positive (23).

\section{Results}

The search criteria used in this review initially identified a total of 351 articles. After screening by the titles and abstracts, 283 articles were excluded, as they did not fit the theme addressed. In addition, 31 were discarded due to design (literature review), duplication in two or more databases, or because they did not meet the proposed inclusion criteria. Thus, 37 works were reviewed by two researchers through a complete reading followed by the application of the pre-defined eligibility criteria for the systematization of evidence. The final result of the search and selection phase included nine articles $(9,10,11,17,24,25$, $26,27,28)$ : six cross-sectional, two prospective cohort, and one case-control studies, all of which were classified as high quality by the identification of the association between WBV and MSD in PTD (Figure 1).

Table 1 - Standardized checklist of methodological quality of the cross-sectional (CS), case-control (CC) and cohort (CO) articles

(To be continued)

\begin{tabular}{|c|c|}
\hline \multicolumn{2}{|l|}{ Aim of the study } \\
\hline 1 Positive, if a particular objective is clearly described & $\mathrm{CA} / \mathrm{CS} / \mathrm{CC} / \mathrm{CO}$ \\
\hline 2 Positive, if the definition of the research question is well defined and contextualized & $\mathrm{CA} / \mathrm{CS} / \mathrm{CC} / \mathrm{CO}$ \\
\hline \multicolumn{2}{|l|}{ Population study } \\
\hline $\begin{array}{l}3 \text { Positive, the main characteristics of the study population are described (sampling procedures } \\
\text { and population distribution by age and sex) }\end{array}$ & $\mathrm{CA} / \mathrm{CS} / \mathrm{CC} / \mathrm{CO}$ \\
\hline $\begin{array}{l}4 \text { Positive, if the sample is representative of the characteristics of interest and sufficient to } \\
\text { avoid bias in the results }\end{array}$ & $\mathrm{CS} / \mathrm{CC} / \mathrm{CO}$ \\
\hline $\begin{array}{l}5 \text { Positive, if cases and controls are drawn from the same population and there is a clear } \\
\text { definition of cases and controls, and those with low back pain in the last three months are } \\
\text { excluded from controls }\end{array}$ & $\mathrm{CC}$ \\
\hline $\begin{array}{l}6 \text { Positive if the participation rate is } \geq 80 \% \text { or if the participation rate is } 60 \%-80 \% \text { and non- } \\
\text { response is not selective (in the presented data) }\end{array}$ & $\mathrm{CS} / \mathrm{CC} / \mathrm{CO}$ \\
\hline $\begin{array}{l}7 \text { Positive if the adherence to the follow-up is } \geq 80 \% \text { or if non-response is not selective (in the } \\
\text { presented data) }\end{array}$ & $\mathrm{CO}$ \\
\hline \multicolumn{2}{|l|}{$\begin{array}{l}\text { Exposure assessment of whole-body vibration [if not included in the project, not } \\
\text { applicable (NA)] }\end{array}$} \\
\hline 8 Positive, if the data are collected and presented & $\mathrm{CA} / \mathrm{CS} / \mathrm{CC} / \mathrm{CO}$ \\
\hline $\begin{array}{l}9 \text { Method for measuring whole-body vibration: direct measurement and observation, interview } \\
\text { or questionnaire }\end{array}$ & $\mathrm{CA} / \mathrm{CS} / \mathrm{CC} / \mathrm{CO}$ \\
\hline $\begin{array}{l}10 \text { Positive, if more than one whole body vibration dimension is measured: frequency, duration } \\
\text { or amplitude }\end{array}$ & $\mathrm{CA} / \mathrm{CS} / \mathrm{CC} / \mathrm{CO}$ \\
\hline 11 Positive, if the monitoring time is adequate / sufficient to avoid bias in the results & $\mathrm{CA} / \mathrm{CS} / \mathrm{CC} / \mathrm{CO}$ \\
\hline 12 Positive, if the data is collected and displayed on the current occupational exposure & $\mathrm{CA} / \mathrm{CS} / \mathrm{CC} / \mathrm{CO}$ \\
\hline
\end{tabular}

Fisioter Mov. 2016 Jan/Mar;29(1):159-72 
Table 1 - Standardized checklist of methodological quality of the cross-sectional (CS), case-control (CC) and cohort (CO) articles

(Conclusion)

\begin{tabular}{|c|c|}
\hline 13 Positive, if the data is collected and if previous occupational exposure is considered & $\mathrm{CA} / \mathrm{CS} / \mathrm{CC} / \mathrm{CO}$ \\
\hline 14 Positive, if the data is collected and a history of musculoskeletal disorders is considered & $\mathrm{CA} / \mathrm{CS} / \mathrm{CC} / \mathrm{CO}$ \\
\hline 15 Positive, if exposure is measured in the same way for cases and controls & CC \\
\hline 16 Positive, if the exposure assessment is masked to the disease state & $\mathrm{CS} / \mathrm{CC}$ \\
\hline 17 Positive, if exposure is assessed at a time before the occurrence of the disease & $\mathrm{CC}$ \\
\hline \multicolumn{2}{|l|}{ Evaluation of results } \\
\hline 18 Positive, if the data were collected for a period $\geq 1$ year & $\mathrm{CO}$ \\
\hline 19 Positive, if the data were collected at least every 3 months & $\mathrm{CO}$ \\
\hline $\begin{array}{l}20 \text { Method to assess musculoskeletal disorders: Masked physical examination for the } \\
\text { condition of exposure }(+) \text {, self-assessment: specific questions related to musculoskeletal } \\
\text { disorders or using anatomical models }(+) \text {, single question }(-)\end{array}$ & $\mathrm{CA} / \mathrm{CS} / \mathrm{CC} / \mathrm{CO}$ \\
\hline 21 Positive, if he results are adequately presented & $\mathrm{CA} / \mathrm{CS} / \mathrm{CC} / \mathrm{CO}$ \\
\hline \multicolumn{2}{|l|}{ Analysis and presentation of data } \\
\hline 22 Positive, if the appropriate statistical model is used & $\mathrm{CS} / \mathrm{CC} / \mathrm{CO}$ \\
\hline 23 Positive, if the analysis is controlled & $\mathrm{CS} / \mathrm{CC} / \mathrm{CO}$ \\
\hline 24 Positive, if all measured variables are presented in the results & $\mathrm{CA} / \mathrm{CS} / \mathrm{CC} / \mathrm{CO}$ \\
\hline \multicolumn{2}{|l|}{ Discussion and Conclusion } \\
\hline 25 Positive, if the evidence supports the conclusions described & $\mathrm{CA} / \mathrm{CS} / \mathrm{CC} / \mathrm{CO}$ \\
\hline
\end{tabular}

Note: Subtitle: $(+)=$ positive; $(-)=$ negative

Source: adapted from van der Windt et al (21). and Hayden, Côté, Bombardier (22).

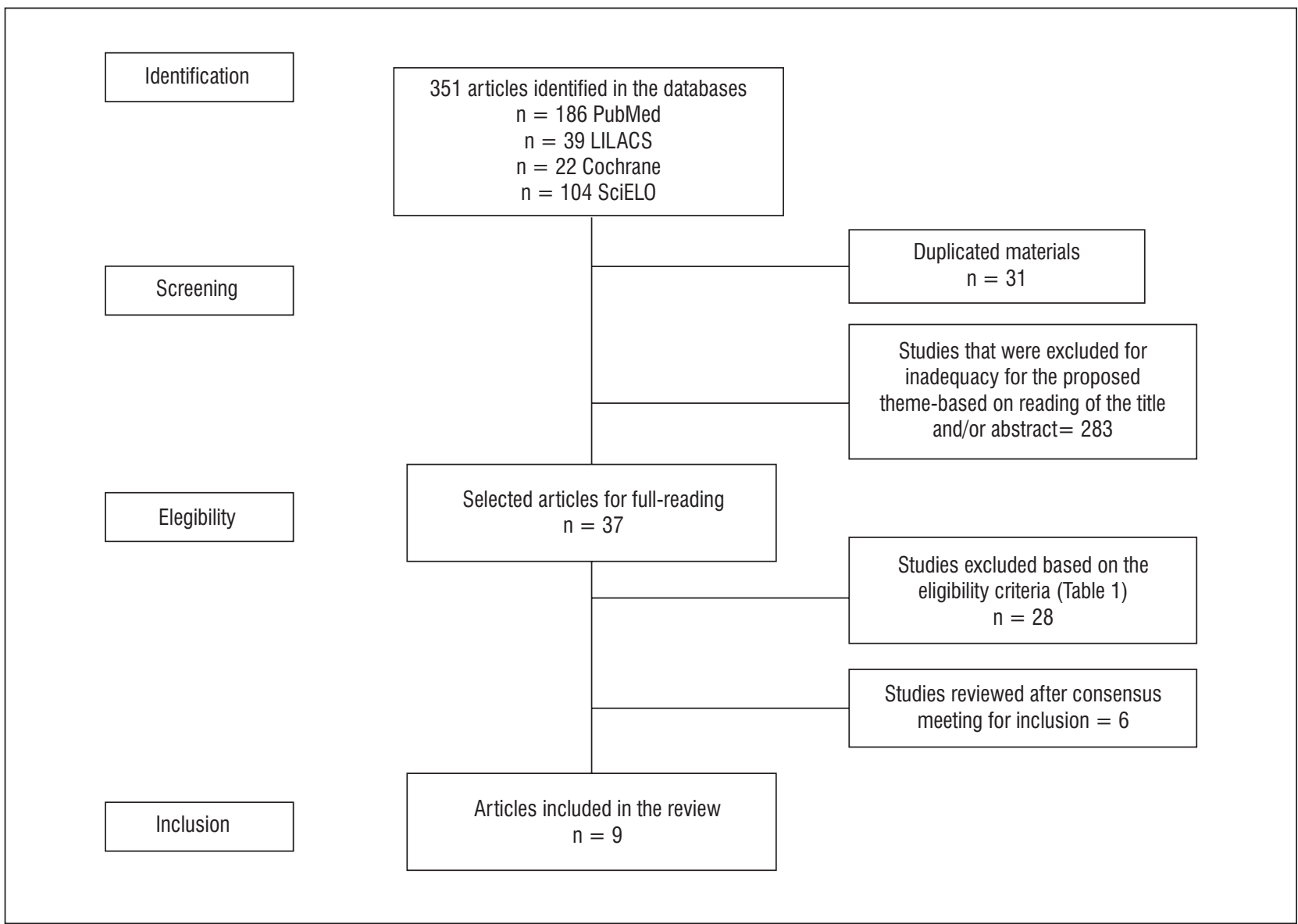

Figure 1- Flow diagram of systematic review inclusion criteria 
Table 2 presents the results of the methodological quality assessment of the selected studies.

The selected articles showed a population of 2173 PTD [2160 were men (99.4\%) and 13 women $(0.6 \%)]$, and samples that ranged from 14 to 598 participants. All studies defined the participants' occupation as PTD. Two studies compared results with a one-year and a two-year follow-up $(11,17)$.
Three studies had women in their sample with a total population percentage of $1.04 \%$ (30), 3.27\% (9) and 42.85\% (29), respectively. Four studies used a group of non-truck drivers as controls $(10,31,32$, 33). All investigations described the sample selection criteria.

Table 3 describes, in detail, the features of the articles selected for this systematic review.

Table 2 - Standardized checklist of methodological quality of the cross-sectional (CS), case-control (CC) and cohort (CO) articles

(To be continued)

\begin{tabular}{|c|c|c|c|c|c|c|c|c|c|}
\hline \multirow[b]{2}{*}{ Criteria(*) } & \multicolumn{9}{|c|}{ Articles } \\
\hline & $\begin{array}{l}\text { Miyamoto } \\
\text { et al., } \\
2000\end{array}$ & $\begin{array}{l}\text { Kumar, } \\
2004\end{array}$ & $\begin{array}{c}\text { Hoy } \\
\text { et al. } 2005\end{array}$ & $\begin{array}{l}\text { Okunribido } \\
\text { et al., } \\
2006\end{array}$ & $\begin{array}{l}\text { Bovenzi et } \\
\text { al., } 2006\end{array}$ & $\begin{array}{l}\text { Robb e } \\
\text { Mansfield, } \\
2007\end{array}$ & $\begin{array}{l}\text { Palmer et } \\
\text { al., } 2008\end{array}$ & $\begin{array}{l}\text { Bovenzi, } \\
2009\end{array}$ & $\begin{array}{c}\text { Bovenzi, } \\
2010\end{array}$ \\
\hline \multicolumn{10}{|l|}{ Aim of the study } \\
\hline 1 & + & + & + & + & + & + & + & + & + \\
\hline 2 & + & + & + & + & + & + & + & + & + \\
\hline \multicolumn{10}{|l|}{ Study population } \\
\hline 3 & + & + & + & + & + & + & + & + & + \\
\hline 4 & + & - & - & - & + & + & + & + & + \\
\hline 5 & NA & NA & NA & NA & NA & NA & - & NA & NA \\
\hline 6 & + & - & + & - & + & + & - & + & + \\
\hline 7 & NA & NA & NA & NA & NA & NA & + & NA & NA \\
\hline \multicolumn{10}{|c|}{$\begin{array}{l}\text { WBV exposure } \\
\text { assessment [if it is } \\
\text { not included in the } \\
\text { study, consider as } \\
\text { "not applicable" (NA)] }\end{array}$} \\
\hline 8 & + & + & + & + & + & + & + & + & + \\
\hline 9 & - & - & + & + & - & - & - & - & - \\
\hline 10 & - & + & + & + & + & + & + & + & + \\
\hline 11 & - & + & + & + & + & + & + & + & + \\
\hline 12 & + & + & + & + & + & + & + & + & + \\
\hline 13 & - & - & - & + & + & - & - & + & + \\
\hline 14 & - & - & + & + & + & + & - & + & + \\
\hline 15 & NA & NA & NA & NA & NA & NA & + & NA & NA \\
\hline 16 & - & - & - & - & + & + & + & NA & NA \\
\hline 17 & NA & NA & NA & NA & NA & NA & - & NA & NA \\
\hline \multicolumn{10}{|l|}{$\begin{array}{l}\text { Assessment of the } \\
\text { study findings }\end{array}$} \\
\hline 18 & NA & NA & NA & NA & NA & NA & NA & + & + \\
\hline 19 & NA & NA & NA & NA & NA & NA & NA & - & - \\
\hline 20 & + & + & + & + & + & + & + & + & + \\
\hline 21 & + & + & + & + & + & + & + & + & + \\
\hline \multicolumn{10}{|l|}{$\begin{array}{l}\text { Analysis and } \\
\text { presentation of } \\
\text { findings }\end{array}$} \\
\hline 18 & NA & NA & NA & NA & NA & NA & NA & + & + \\
\hline 19 & NA & NA & NA & NA & NA & NA & NA & - & - \\
\hline 20 & + & + & + & + & + & + & + & + & + \\
\hline 21 & + & + & + & + & + & + & + & + & + \\
\hline
\end{tabular}


Table 2 - Standardized checklist of methodological quality of the cross-sectional (CS), case-control (CC) and cohort (CO) articles

(Conclusion)

\begin{tabular}{|c|c|c|c|c|c|c|c|c|c|}
\hline \multirow[b]{2}{*}{ Criteria(*) } & \multicolumn{9}{|c|}{ Articles } \\
\hline & $\begin{array}{l}\text { Miyamoto } \\
\text { et al., } \\
2000\end{array}$ & $\begin{array}{l}\text { Kumar, } \\
2004\end{array}$ & $\begin{array}{c}\text { Hoy } \\
\text { et al. } 2005\end{array}$ & $\begin{array}{l}\text { Okunribido } \\
\text { et al., } \\
2006\end{array}$ & $\begin{array}{l}\text { Bovenzi et } \\
\text { al., } 2006\end{array}$ & $\begin{array}{l}\text { Robb e } \\
\text { Mansfield, } \\
2007\end{array}$ & $\begin{array}{l}\text { Palmer et } \\
\text { al., } 2008\end{array}$ & $\begin{array}{l}\text { Bovenzi, } \\
2009\end{array}$ & $\begin{array}{l}\text { Bovenzi, } \\
2010\end{array}$ \\
\hline $\begin{array}{l}\text { Analysis and } \\
\text { presentation of } \\
\text { findings }\end{array}$ & & & & & & & & & \\
\hline 22 & + & + & + & + & + & + & + & + & + \\
\hline 23 & + & + & + & + & + & + & + & + & + \\
\hline 24 & + & - & + & + & + & + & + & + & + \\
\hline $\begin{array}{l}\text { Discussion and final } \\
\text { considerations } \\
25\end{array}$ & - & + & + & + & + & + & + & + & + \\
\hline $\begin{array}{l}\text { Positive results } \\
\text { regarding the study } \\
\text { quality of the methods } \\
\text { (\%) }\end{array}$ & 63.2 & 63.2 & 78.9 & 84.2 & 84.2 & 89.5 & 73.9 & 78.3 & 78.3 \\
\hline
\end{tabular}

Note: Subtitle: $\left({ }^{*}\right)$ Criteria correspondent to those described in table 1

Table 3 - Characteristics of the articles selected for systematic review

(To be continued)

\begin{tabular}{|c|c|c|c|c|c|}
\hline \multicolumn{3}{|c|}{ Study characteristics } & Methods & Results & Conclusions \\
\hline $\begin{array}{l}\text { Authors } \\
\text { (Year) }\end{array}$ & Objectives & $\begin{array}{l}\text { Sampling } \\
\text { (age) }\end{array}$ & $\begin{array}{l}\text { Procedures, } \\
\text { instruments and } \\
\text { statistical analysis }\end{array}$ & & \\
\hline Study design & & & & & \\
\hline $\begin{array}{l}\text { Miyamoto; } \\
\text { Shirai; } \\
\text { Nakayama; } \\
\text { Gembun; Kaneda } \\
\text { (2000) } \\
\text { Cross-sectional }\end{array}$ & $\begin{array}{l}\text { Investigate the } \\
\text { prevalence } \\
\text { of back pain } \\
\text { symptoms and } \\
\text { its risk factors } \\
\text { among PTD } \\
\text { by using a } \\
\text { questionnaires }\end{array}$ & $\begin{array}{l}148 \text { men e } 5 \\
\text { women } \\
\text { (19-61 years } \\
\text { old) }\end{array}$ & $\begin{array}{l}\text { A questionnaire on } \\
\text { symptoms of low } \\
\text { back pain, analysis } \\
\text { of personal and } \\
\text { occupational factors } \\
\text { was applied. } \\
\text { Student's t-test } \\
\text { Logistic regression, } \\
\text { odds ratios and 95\% } \\
\text { confidence interval. }\end{array}$ & $\begin{array}{l}\text { Prevalence of symptoms of } \\
\text { low back pain in } 50.3 \% \text { of } \\
\text { the sample. High correlation } \\
\text { between personal factors } \\
\text { and low back pain (odds } \\
\text { ratio }=2.7,95 \% \mathrm{Cl} 1.3 \\
\text { to } 5.4 \text { ) regarding the item } \\
\text { "spend time recently with } \\
\text { my family". High correlation } \\
\text { between occupational } \\
\text { factors: irregular scale work } \\
\text { (0dds Ratio = 3.0, } 95 \% \mathrm{Cl} \\
1.3 \text { to } 7.0 \text { ), little time to rest } \\
\text { (0dds Ratio = } 2.4,95 \% \mathrm{Cl} \\
1,24.7 \text { ) and long driving } \\
\text { hours (odds ratio = } 2.0 \text {, } \\
95 \% \text { Cl } 1.0 \text { to } 4.3 \text { ). } 52.9 \% \\
\text { of the sample indicated } \\
\text { relationship between low } \\
\text { back pain and WBV. }\end{array}$ & $\begin{array}{l}\text { There is a high prevalence } \\
\text { of low back pain in PTD. } \\
\text { WBV is a major risk factor } \\
\text { in the occurrence of the } \\
\text { symptoms of low back } \\
\text { pain in PTD. Prophylactic } \\
\text { measures at the personal, } \\
\text { organizational and } \\
\text { environmental level are } \\
\text { important for low back pain } \\
\text { prevention. }\end{array}$ \\
\hline
\end{tabular}


Table 3 - Characteristics of the articles selected for systematic review

(To be continued)

\begin{tabular}{|c|c|c|c|c|c|}
\hline \multicolumn{3}{|c|}{ Study characteristics } & \multirow{3}{*}{$\begin{array}{l}\text { Methods } \\
\text { Procedures, } \\
\text { instruments and } \\
\text { statistical analysis }\end{array}$} & \multirow[t]{2}{*}{ Results } & \multirow[t]{2}{*}{ Conclusions } \\
\hline $\begin{array}{l}\text { Authors } \\
\text { (Year) }\end{array}$ & Objectives & $\begin{array}{l}\text { Sampling } \\
\text { (age) }\end{array}$ & & & \\
\hline Study design & & & & & \\
\hline $\begin{array}{l}\text { Kumar } \\
(2004)\end{array}$ & $\begin{array}{l}\text { Investigate the } \\
\text { WBV level among } \\
\text { seated PTD } \\
\text { during operation } \\
\text { in mining }\end{array}$ & $\begin{array}{l}8 \text { men } \\
\text { (32-55 years } \\
\text { old) } \\
6 \text { women } \\
\text { (23-49 years } \\
\text { old) }\end{array}$ & $\begin{array}{l}\text { WBV (triaxial } \\
\text { accelerometer) on the } \\
\text { truck seat, L3 and C7. } \\
\text { Descriptive analysis } \\
\text { and } \\
\text { MANOVA }\end{array}$ & $\begin{array}{l}\text { The WBV in the seat ranged } \\
\text { from } 0.37 \text { to } 11.73 \text { by } \mathrm{m} / \mathrm{s}^{2} ; \\
\text { at the back from } 0.34 \text { to } \\
2.72 \mathrm{~m} / \mathrm{s}^{2} \text {; in the cervical } \\
\text { from } 0.2 \text { to } 2.22 \mathrm{~m} / \mathrm{s}^{2} \text {. } \\
\text { Gender, driving aspects } \\
\text { and loaded cargo had no } \\
\text { significant effect on the } \\
\text { WBV levels. } \\
\text { The body mass of the } \\
\text { driver, old truck, truck } \\
\text { type and the experience of } \\
\text { the driver, as well as their } \\
\text { interactions, had significant } \\
\text { effects on the WBV levels }\end{array}$ & $\begin{array}{l}\text { The PTD working in mining } \\
\text { activities are significantly } \\
\text { exposed to health risks. The } \\
\text { greatest risks are linked to } \\
\text { the WBV exposure level that } \\
\text { exceeds the limits for most } \\
\text { of the working day. }\end{array}$ \\
\hline $\begin{array}{l}\text { Hoy; Mubarak; } \\
\text { Nelson; Sweerts } \\
\text { de Landas; } \\
\text { Magnusson; } \\
\text { Okunribido; Pope } \\
\text { (2005) } \\
\text { Cross-sectional }\end{array}$ & $\begin{array}{l}\text { Investigate the } \\
\text { risks of WBV } \\
\text { and postural } \\
\text { demands in the } \\
\text { occurrence of } \\
\text { low back pain }\end{array}$ & $\begin{array}{l}23 \text { PTD and } \\
23 \text { controls } \\
\text { (non- PTD) }\end{array}$ & $\begin{array}{l}\text { Demographics } \\
\text { data, Questionnaire } \\
\text { on lifestyle, job } \\
\text { satisfaction, } \\
\text { occupational and health } \\
\text { factors. } \\
\text { Posture assessment } \\
\text { (OWAS and RULA), } \\
\text { WBV measures (triaxial } \\
\text { accelerometer) } \\
\text { Descriptive analysis, } \\
\text { univariate analysis }\end{array}$ & $\begin{array}{l}\text { Higher prevalence of } \\
\text { low back pain in drivers } \\
\text { compared to non- } \\
\text { drivers. PTD presented } \\
\text { an occurrence two times } \\
\text { higher than others (OR } \\
3.516,95 \% \mathrm{Cl} 1044- \\
11828 \text { ). Smoking, physical } \\
\text { activity and job satisfaction } \\
\text { were not significant in the } \\
\text { prevalence of low back } \\
\text { pain. Body posture is a } \\
\text { determining factor in the } \\
\text { occurrence of low back } \\
\text { pain. Satisfactory levels of } \\
\text { exposure to WBV, but with } \\
\text { influence over the assumed } \\
\text { posture. }\end{array}$ & $\begin{array}{l}\text { There is a high prevalence } \\
\text { of low back pain in PTD. } \\
\text { The WBV is influenced by } \\
\text { other factors. The number } \\
\text { of working hours is a factor } \\
\text { to be considered in the } \\
\text { analysis of low back pain } \\
\text { and may be associated with } \\
\text { other factors such as type } \\
\text { of seat, displacements and } \\
\text { spine movement during } \\
\text { working hours, exposure } \\
\text { to WBV on vehicle loading } \\
\text { conditions }\end{array}$ \\
\hline $\begin{array}{l}\text { Okunribido; } \\
\text { Magnuson; Pope } \\
\text { (2006) } \\
\text { Cross-sectional }\end{array}$ & $\begin{array}{l}\text { To investigate } \\
\text { the role of WBV, } \\
\text { posture and } \\
\text { manual labor as } \\
\text { risk factors for } \\
\text { low back pain }\end{array}$ & $\begin{array}{l}369 \text { PTD e } \\
49 \text { non- } \\
\text { drivers } \\
\text { individuals } \\
\text { (control) }\end{array}$ & $\begin{array}{l}\text { Questionnaire on } \\
\text { health history, posture } \\
\text { and manual activities } \\
\text { and direct measures } \\
\text { of WBV (triaxial } \\
\text { accelerometer), } \\
\text { posture and manual } \\
\text { activities score. } \\
\\
\text { Logistic Regression, } \\
\text { Odds Ratio, 95\% } \\
\text { confidence interval } \\
\text { Log-linear models }\end{array}$ & $\begin{array}{l}55.7 \% \text { reported low back } \\
\text { pain in the last } 12 \text { months } \\
\text { (LBP). } 30.1 \% \text { reported } \\
\text { acute symptoms (ABP). } \\
\text { Increased occurrence of } \\
\text { LBP / ABP-related to the } \\
\text { sitting working condition } \\
\text { (OR }=2.420,95 \% \mathrm{Cl} \\
1.450 \text { to } 24.036 / \mathrm{OR}= \\
2.182,95 \% \mathrm{Cl} 1.341 \text { to } \\
3.552) \text {, and trunk rotation } \\
(\mathrm{OR}=2.644 ; 95 \% \mathrm{Cl} \\
1,745-4,005 / \mathrm{OR}= \\
2.158,95 \% \mathrm{Cl} 1.380 \text { to } \\
3.376) \text {. Discomfort by WBV } \\
\text { associated with the LPB / } \\
\text { APB (OR = 5.553, 95\% } \\
\mathrm{Cl} 3.387 \text { to } 9.102 / \mathrm{OR}= \\
4.044,95 \% \mathrm{Cl} 2.502 \text { to } \\
6.537) \text {. }\end{array}$ & $\begin{array}{l}\text { The increased occurrence } \\
\text { of low back pain is } \\
\text { associated with the } \\
\text { combination of body } \\
\text { posture and WBV and / or } \\
\text { more manual activities than } \\
\text { the exposure of a single } \\
\text { factor. }\end{array}$ \\
\hline
\end{tabular}


Table 3 - Characteristics of the articles selected for systematic review

(To be continued)

\begin{tabular}{|c|c|c|c|c|c|}
\hline \multicolumn{3}{|c|}{ Study characteristics } & \multirow{3}{*}{$\begin{array}{l}\text { Methods } \\
\text { Procedures, } \\
\text { instruments and } \\
\text { statistical analysis }\end{array}$} & \multirow[t]{2}{*}{ Results } & \multirow[t]{3}{*}{ Conclusions } \\
\hline $\begin{array}{c}\text { Authors } \\
\text { (Year) }\end{array}$ & Objectives & $\begin{array}{l}\text { Sampling } \\
\text { (age) }\end{array}$ & & & \\
\hline Study design & & & & & \\
\hline $\begin{array}{l}\text { Bovenzi et al. } \\
\text { (2006) } \\
\text { Cross-sectional }\end{array}$ & $\begin{array}{l}\text { To investigate } \\
\text { the prevalence of } \\
\text { low back pain in } \\
\text { Italian PTD. } \\
\text { Analyze the } \\
\text { association of } \\
\text { WBV, physical } \\
\text { overload } \\
\text { psychosocial } \\
\text { aspects with low } \\
\text { back pain. }\end{array}$ & $\begin{array}{l}598 \text { men } \\
\text { (PTD) } \\
30 \text { controls } \\
\text { (non- PTD) }\end{array}$ & $\begin{array}{l}\text { Demographics data, } \\
\text { questionnaire on } \\
\text { occupational and health } \\
\text { records. } \\
\text { WBV (triaxial } \\
\text { accelerometer) } \\
\text { Roland-Morris } \\
\text { Questionnaire and pain } \\
\text { scale of Von Korff } \\
\text { Descriptive analysis, } \\
\text { Student's t test, } \\
\text { ANOVA, chi-square } \\
\text { test, logistic regression } \\
\text { Odds Ratio 95\% } \\
\text { Confidence Interval }\end{array}$ & $\begin{array}{l}\text { The daily exposure to WBV } \\
\text { varies from } 0.1 \text { to } 1.18 \mathrm{~m} / \mathrm{s}^{2} \text {. } \\
\text { The duration of exposure } \\
\text { to WBV ranged from } 1-41 \\
\text { years long. The prevalence } \\
\text { of chronic low back pain } \\
\text { (12 months) and acute } \\
\text { low back pain ( } 7 \text { days) } \\
\text { was higher in the group of } \\
\text { drivers (OR }=4.49,95 \% \mathrm{Cl} \\
1.05 \text { to } 19.2) / \text { than in the } \\
\text { control group (OR }=2.81 \text {, } \\
\mathrm{Cl} 95 \% 1.31 \text { to } 6.04) \text {. The } \\
\text { occurrence of lower back } \\
\text { pain, increased intensity of } \\
\text { symptoms and functional } \\
\text { disability are associated } \\
\text { to an increase in the } \\
\text { cumulative exposure level } \\
\text { to WBV. Individual factors } \\
\text { and the physical burden } \\
\text { index at work are significantly } \\
\text { associated with the degree } \\
\text { of back pain, whereas } \\
\text { psychosocial factors have } \\
\text { a marginal association with } \\
\text { symptoms of lower back } \\
\text { pain. }\end{array}$ & $\begin{array}{l}\text { PTD have increased } \\
\text { risk for low back pain } \\
\text { associated with the } \\
\text { work. Exposure to WBV } \\
\text { and factors at work that } \\
\text { lead to physical overload } \\
\text { are important factors in } \\
\text { multifactor composition of } \\
\text { low back pain onset in this } \\
\text { profession. }\end{array}$ \\
\hline $\begin{array}{l}\text { Robb e Mansfield } \\
(2007) \\
\text { Cross-sectional }\end{array}$ & $\begin{array}{l}\text { Examine the } \\
\text { relationship } \\
\text { between MSD } \\
\text { and possible } \\
\text { risk factors for } \\
\text { PTD in heavy } \\
\text { vehicles, in } \\
\text { order to develop } \\
\text { WBV exposure } \\
\text { reduction actions }\end{array}$ & $\begin{array}{l}190 \text { men } \\
2 \text { women } \\
\text { (all PTD) } \\
\text { (22-71 years } \\
\text { old) }\end{array}$ & $\begin{array}{l}\text { A questionnaire on, } \\
\text { demographic data, } \\
\text { description of the job, } \\
\text { exposure to WBV, } \\
\text { report of MSD. } \\
\text { Descriptive analysis; } \\
\text { T-test for independent } \\
\text { samples, chi-square; } \\
\text { Pearson's coefficient }\end{array}$ & $\begin{array}{l}\text { Exposure to WBV varies } \\
\text { from } 12 \text { to } 85 \text { hours per } \\
\text { week (average } 43,8 \text { hours), } \\
\text { distance traveled during } \\
\text { working hours } 256 \text { - } \\
6400 \mathrm{~km} \text { per week (average } \\
2469 \mathrm{~km}) ; 81 \% \text { of the } \\
\text { sample reported MSD in } \\
\text { the past } 12 \text { months, } 60 \% \\
\text { reported lower back pain. } \\
\text { Significant relationship } \\
\text { between distance and } \\
\text { MSD (p <0.01) and no } \\
\text { significant time between } \\
\text { exposure and MSD. }\end{array}$ & $\begin{array}{l}\text { There is a positive } \\
\text { association between } \\
\text { symptoms of MSD and } \\
\text { distance travelled with } \\
\text { the truck. Risk reduction } \\
\text { strategies should aim to } \\
\text { cargo handling and comfort } \\
\text { of the vehicle seat }\end{array}$ \\
\hline
\end{tabular}


Table 3 - Characteristics of the articles selected for systematic review

(To be continued)

\begin{tabular}{|c|c|c|c|c|c|}
\hline \multicolumn{3}{|c|}{ Study characteristics } & \multirow{3}{*}{$\begin{array}{l}\text { Methods } \\
\text { Procedures, } \\
\text { instruments and } \\
\text { statistical analysis }\end{array}$} & \multirow[t]{2}{*}{ Results } & \multirow[t]{3}{*}{ Conclusions } \\
\hline $\begin{array}{l}\text { Authors } \\
\text { (Year) }\end{array}$ & Objectives & $\begin{array}{l}\text { Sampling } \\
\text { (age) }\end{array}$ & & & \\
\hline Study design & & & & & \\
\hline $\begin{array}{l}\text { Palmer; Bennett; } \\
\text { Reading; } \\
\text { Sampson; } \\
\text { Coggon } \\
\text { (2008) } \\
\text { Case-control }\end{array}$ & $\begin{array}{l}\text { Investigate the } \\
\text { risk factors for } \\
\text { low back pain } \\
\text { apparent in MRI } \\
\text { scan focusing on } \\
\text { WBV analysis }\end{array}$ & $\begin{array}{l}185 \text { PTD } \\
42 \text { cases and } \\
143 \text { controls }\end{array}$ & $\begin{array}{l}\text { Cases with back pain } \\
\text { examined by MRI } \\
\text { scan and Controls } \\
\text { analyzed by X-ray. } \\
\text { Demographic analysis, } \\
\text { factors of spine } \\
\text { overload, psychosocial } \\
\text { factors, driving } \\
\text { aspects, personal } \\
\text { characteristics, mental } \\
\text { health. Roland-Morris } \\
\text { Questionnaire, SF-36, } \\
\text { Karasek Model of } \\
\text { Demand-Control. } \\
\text { Descriptive analysis } \\
\text { Logistic regression } \\
\text { Odds Ratio 95\% } \\
\text { Confidence Interval }\end{array}$ & $\begin{array}{l}\text { Strong association found } \\
\text { between poor mental health } \\
\text { and work as a causal } \\
\text { factor for low back pain. } \\
\text { Correlation with the sitting } \\
\text { position for more than } 3 \\
\text { hours at work. } \\
\text { Association with } \\
\text { anthropometric data, body } \\
\text { mass index, smoking, } \\
\text { beliefs, low support } \\
\text { at work, and physical } \\
\text { demands of rotation. Weak } \\
\text { association with the WBV } \\
\text { measures. } \\
\text { There was no correlation } \\
\text { between exposure and } \\
\text { outcome. }\end{array}$ & $\begin{array}{l}\text { Weak evidence on the } \\
\text { relationship of back pain } \\
\text { and WB when MRI scan is } \\
\text { used as a parameter for the } \\
\text { analysis of low back pain. }\end{array}$ \\
\hline $\begin{array}{l}\text { Bovenzi } \\
\text { (2009) } \\
\text { Prospective } \\
\text { Cohort }\end{array}$ & $\begin{array}{l}\text { Investigate the } \\
\text { relationship } \\
\text { between } \\
\text { alternative } \\
\text { measures of } \\
\text { WBV and back } \\
\text { pain among PTD }\end{array}$ & $\begin{array}{l}\text { Target } \\
\text { populations } \\
\mathrm{N}=628 \\
\text { PTD: } 598 \\
\text { acceptances } \\
\& 30 \text { refusals. } \\
\text { 2-years } \\
\text { follow-up } \\
\mathrm{n}=537 \\
61 \\
\text { withdrawals } \\
\text { 1st year of } \\
\text { follow-up } \\
\text { (2004-2005): } \\
\mathrm{n}=220 ; 2^{\text {nd }} \\
\text { year of follow } \\
\text { up (2005- } \\
2006) \text { : } \\
\mathrm{n}=317\end{array}$ & $\begin{array}{l}\text { Questionnaires on } \\
\text { demographic data, } \\
\text { occupational history, } \\
\text { health conditions, MSD } \\
\text { symptoms, } \\
\text { WBV measure: triaxial } \\
\text { accelerometer } \\
\text { Exposure time: self- } \\
\text { report. } \\
\text { Other: physical factors } \\
\text { (image analysis) and } \\
\text { psychosocial (JCQ). } \\
\text { Descriptive analysis; } \\
\text { Wilcoxon test, Kruskal- } \\
\text { Wallis test, chi-square, } \\
\text { logistic regression } \\
\text { Odds Ratios and } \\
\text { confidence interval of } \\
\text { 95\% }\end{array}$ & $\begin{array}{l}36.3 \% \text { incidence of low } \\
\text { back pain in } 12 \text { months } \\
\text { with } 24.6 \% \text { of high levels of } \\
\text { pain intensity and } 19.2 \% \text { of } \\
\text { disability. }\end{array}$ & $\begin{array}{l}\text { Increased risk of developing } \\
\text { high levels of pain and } \\
\text { disability associated with } \\
\text { back pain due to increasing } \\
\text { magnitude of WBV } \\
\text { exposure time among PTD } \\
\text { and machine operators. }\end{array}$ \\
\hline
\end{tabular}


Table 3 - Characteristics of the articles selected for systematic review

(Conclusion)

\begin{tabular}{|c|c|c|c|c|c|}
\hline \multicolumn{3}{|c|}{ Study characteristics } & \multirow{3}{*}{$\begin{array}{l}\text { Methods } \\
\text { Procedures, } \\
\text { instruments and } \\
\text { statistical analysis }\end{array}$} & \multirow[t]{2}{*}{ Results } & \multirow[t]{3}{*}{ Conclusions } \\
\hline $\begin{array}{l}\text { Authors } \\
\text { (Year) }\end{array}$ & Objectives & $\begin{array}{l}\text { Sampling } \\
\text { (age) }\end{array}$ & & & \\
\hline Study design & & & & & \\
\hline $\begin{array}{l}\text { Bovenzi } \\
(2010) \\
\text { Prospective } \\
\text { cohort }\end{array}$ & $\begin{array}{l}\text { Investigate the } \\
\text { relationship } \\
\text { between low } \\
\text { back pain } \\
\text { and results of } \\
\text { measures of } \\
\text { daily exposure to } \\
\text { WBV among PTD }\end{array}$ & $\begin{array}{l}202 \text { PTD. } \\
\text { Follow-up } \\
\text { time (2 } \\
\text { years): } \\
1^{\text {st }} \text { year of } \\
\text { follow-up } \\
(2004-2005) \text { : } \\
n=92 ; 2^{\text {nd }} \\
\text { year of follow } \\
\text { up (2005- } \\
2006): n= \\
110\end{array}$ & $\begin{array}{l}\text { Questionnaires on } \\
\text { demographic data, } \\
\text { occupational history, } \\
\text { health conditions, MSD } \\
\text { symptoms } \\
\text { Nordic questionnaire } \\
\text { for WBV measure } \\
\text { (triaxial accelerometer) } \\
\text { Pain intensity. Other: } \\
\text { physical factors } \\
\text { (image analysis) and } \\
\text { psychosocial (JCQ) } \\
\text { Descriptive analysis; } \\
\text { Wilcoxon test, Kruskal- } \\
\text { Wallis test, chi-square, } \\
\text { Logistic Regression } \\
\text { Odds Ratios and } \\
\text { confidence interval of } \\
\text { 95\% }\end{array}$ & $\begin{array}{l}\text { Cumulative incidence of } \\
\text { back pain of } 38.6 \% \text { in the } \\
\text { follow-up; } 16.8 \% \text { had high } \\
\text { intensity pain and } 14.4 \% \\
\text { presented disability }\end{array}$ & $\begin{array}{l}\text { The workload is presented } \\
\text { as a predictor for the } \\
\text { outcome of low back pain } \\
\text { and psychosocial factors } \\
\text { are not associated with low } \\
\text { back pain in the workplace. }\end{array}$ \\
\hline
\end{tabular}

\section{Discussion}

This study aimed to conduct a literature review and investigate the association between exposure to WBV and MSD. The finding of this systematization of evidence suggests an association between exposure to WBV in PTD in the event of MSD, especially due to the observation of high prevalence of low back pain and symptoms resulting from this condition.

The PTD are exposed to injuries in the cervical and lumbar spine, pressure points and poor circulation in the legs and buttocks, resulting from long periods in the sitting position. Furthermore, they may increase their risk of injury when handling objects, in addition to their usual occupation activities (30).

These professionals have a higher prevalence of low back pain, which presents greater intensity when compared to the other drivers (10). The age of the vehicle, the driver's body mass and other organizational factors appear as significant variables in the negative impact caused by the exposure to the WBV (24). The posture assumed during the driving operation, along with the WBV exposure is another variable that may be identified as associated with back pain (33).
The physiological effects of this condition can be explained by the posture taken by the employee during his/her working hours, associated with the organic-structural conditions of the individual who is subjected to adverse environmental conditions (33). As a result of this issue, one can highlight the capacity ratio of that person to deal and interact with these exposure factors that trigger MSD and manifest themselves in the form of a disease. That person builds this capacity through strategies during his working life. $(11,30,33)$.

According to Dejours (34) the "work organization is defined as the division of labor and of men." The prescription precedes the task execution, and composes a record that meets the need for guidance, bureaucratization and inspection, being a source for both recognition and punishment. The real work is one that happens at the very moment of its execution. Time of weekly exposure to WBV and the distance driven were variables that have been observed and associated with the occurrence of MSD (26). The intensity of pain and the incapacity for work are manifested directly with increasing exposure gradients $(17,27)$. 
The PTD who has a sedentary lifestyle and finds himself exposed to high levels of WBV associated with the density and intensity of working hours, may increase the damage to his health, once he is at the limit required for systemic functioning (30). Such factors predispose the PTD to health problems such as MSD affecting his overall physical ability, with consequent impairment in the production process and impact on the healthcare system. The consequences of this relationship are highlighted in the individual's removal as a "social being" and in the physical impairments that can lead to mental impairment.

The majority of workers, while reporting MSD, only considered those diseases as a limiting factor for work when they are unable to perform their occupational activities. They use the knowledge acquired with the working practice to put them forward in a situation in which they are exposed to risks, such as in the case of WBV exposure.

Among the studies chosen for review, after the application of the selection criteria, we did not find evidence for the relevance of WBV exposure to health issues except in the case-control study developed by Palmer et al. (28). The authors explain their findings by the conditions of the sample cases in relation to the period of WBV exposure, which was after the occurrence of low back pain; and by the diversity of activities present by the drivers. They suggest that exposure to WBV may be not the main cause of severe back pain; instead, the mental aspects and the perception of general health have a more significant contribution with stronger association with the occurrence of low back pain in the sample. However, two studies of cohort/longitudinal design, developed by Bovenzi $(11,17)$, stressed the importance of WBV exposure in the onset of low back pain. Those studies present a greater power of risk elucidation and less vulnerability to bias.

This systematic review sought to raise current and scientifically proven evidence to assist the development of diagnostic analysis and MSD management for PTD. The quality of the selected studies was verified, as well as the control of the following possible confounding variables to the analyzed outcome: other salient exposure in the labor process, associated with the diversity of the driver's work (weight lifting, prolonged sitting, twisting of trunk, among others). However, there is no consensus in the available literature on the subject, when it comes to the establishment of a dose-response association.

\section{Final Considerations}

In this systematic review study on the importance of WBV exposure and MSD, we identified that organizational factors and operating conditions may directly or indirectly affect WBV exposure, and they must be considered in the analysis of the physical harms associated with PTD work. There are some examples of factors that must be addressed with intervention measures at the level of prevention and health promotion, such as: long journeys and working hours that cause longer exposure times to WBV, body postures assumed while driving the vehicle, the influence of the work organization, the value of the exposure magnitude affected by the age of the vehicle, road conditions and others. This review's findings identified that the included studies presented methodological quality on the subject, which provides solid and sufficient evidence to reduce WBV exposure to the lowest possible in order to prevent the occurrence of MSD, especially low back pain among PTD. The study subject, from an epidemiological point of view, should place more value on prospective studies with more consistency and less on those, which only seek association.

\section{References}

1. Caldbick S, Labonte R, Mohindra KS, Ruckert A. Globalization and the rise of precarious employment: the new frontier for workplace health promotion. Glob Health Promot. 2014;21(2):23-31.

2. Ruiz VS, Araújo ALL. Health and safety, and subjectivity at work: the psychosocial risks. Rev Bras Saúde Ocup. 2012;37:170-80.

3. Matos MG, Hennington EA, Hoefel AL, Dias-da-Costa JS. Lower back pain in health insurance policyholders: prevalence and associated factors. Cad Saúde Pública. 2008; 24:2115-22.

4. Carter B, Danford A, Howcroft D, Richardson H, Smith A, Taylor P. 'Stressed out of my box': employee experience of lean working and occupational ill-health in clerical work in the UK public sector. Work Employ Soc. 2013; 27:747-67.

5. Härmä M, Kompier MAJ, Vahtera J. Work-related stress and health - risks, mechanisms and countermeasures. Scand J Work Environ Health. 2006; 32:413-19. 
6. Neri M, Soares WL, Soares C. Health conditions in the cargo and passenger road transportation industry: a study based on the Brazilian National Sample Household Survey. Cad Saúde Pública. 2005;21:1107-23.

7. Kuijer W, Groothoff JW, Brouwer S, Geertzen JHB, Dijkstra PU. Prediction of Sickness Absence in Patients with Chronic Low Back Pain: A Systematic Review. J Occup Rehabil. 2006;16:439-67.

8. Coggon D, Ntani G, Palmer KT, Felli VE, Harari R, et al. Disabling musculoskeletal pain in working populations: is it the job, the person, or the culture? Pain. 2013;154:856-63.

9. Miyamoto M, Shirai Y, Nakayama Y, Gembun Y, Kaneda K. An epidemiologic study of occupational low back pain in truck drivers. J Nippon Med Sch. 2000;67:186-90.

10. Hoy J, Mubarak N, Nelson S, Sweerts de Landas M, Magnusson M, Okunribido O, Pope M. Whole body vibration and posture as risk factors for low back pain among forklift truck drivers. J Sound Vib. 2005;284:933-46.

11. Bovenzi M. A longitudinal study of low back pain and daily vibration exposure in professional drivers. Ind Health. 2010;48:584-95

12. Boshuizen HC, Bongers PM, Hulshof CTJ. Back disorders and occupational exposure to whole-body vibration. Int J Ind Ergonomics. 1990a;6:55-9.

13. Donoghue AM. Occupational health hazards in mining: an overview. Occup Med (Lond). 2004;54:283-9.

14. Pope MH, Wilder DG, Magnusson M. Possible mechanisms of low back pain due to whole-body vibration. J Sound Vibr.1998;215:687-97.

15. Vanerkar AP, Kulkarni NP, Zade PD, Kamavisdar AS. Whole body vibration exposure in heavy earth moving machinery operators of metalliferrous mines. Environ Monit Assess. 2008;143:239-45.

16. Rehn B, Nilsson T, Lundström R, Hagberg M, Burström L. Neck pain combined with arm pain among professional drivers of forest machines and the association with whole-body vibration exposure. Ergonomics. 2009;52:1240-7.
17. Bovenzi M. Metrics of whole-body vibration and exposure-response relationship for low back pain in professional drivers: a Estudo de coorte prospectivo. Int Arch Occup Environ Health. 2009;82:893-917.

18. Saporiti AF, Borges LH, Salaroli LB, Molina MDCB. Dores osteomusculares e fatores associados em motoristas de carretas nas rodovias do Espírito Santo. Revista Brasileira de Pesquisa em Saúde. 2010;1272-8.

19. Bovenzi M, Hulshof CT. An updated review of epidemiologic studies on the relationship between exposure to whole-body vibration and low back pain (1986-1997). Int Arch Occup Environ Health. 1999;72:351-65.

20. Lings S, Leboeuf-YC. Whole-body vibration and low back pain: a systematic, critical review of the epidemiological literature 1992-1999. Int Arch Occup Environ Health. 2000 Jul;73(5):290-7.

21. Van der Windt DA, Thomas E, Pope DP, de Winter AF, Macfarlane GJ, Bouter LM, Silman AJ. Occupational risk factors for shoulder pain: a systematic review. Occup Environ Med 2000;57:433-42.

22. Hayden JA, Côté P, Bombardier C. Evaluation of the Quality of Prognosis Studies in Systematic Reviews. Ann Intern Med. 2006;144:427-37.

23. Hoogendoorn WE, van Poppel MN, Bongers PM, Koes BW, Bouter LM. Systematic Review of Psychosocial Factors at Work and Private Life as Risk Factors for Back Pain. Spine. 2000;25(16): 2114-25.

24. Kumar S. Vibration in operating heavy haul trucks in overburden mining. Appl Ergon. 2004;35(6):509-20.

25. Okunribido, O.O.; Magnuson, M; Pope, M.H. Low back pain in drivers: The relative role of whole-body vibration, posture and manual materials handling. J Sound Vib. 2006;298:540-55.

26. Robb MJ, Mansfield NJ. Self-reported musculoskeletal problems amongst professional truck drivers. Ergonomics. 2007;50:814-27.

27. Bovenzi M, Rui F, Negro C, D’Agostin F, Angotzi G, Bianchi S, Bramanti L, Festa GL, Gatti S, Pinto I, Rondina L, Stacchini N. An epidemiological study of low back pain in professional drivers. J Sound Vibr. 2006;298:514-39. 
28. Palmer KT, Harris EC, Griffin MJ, Bennett J, Reading I, Sampson M, Coggon D. Case-control study of low-back pain referred for magnetic resonance imaging, with special focus on whole-body vibration. Scand J Work Environ Health. 2008;34:364-73.

29. Smets MP, Eger TR, Grenier SG. Whole-body vibration experienced by haulage truck operators in surface mining operations: a comparison of various analysis methods utilized in the prediction of health risks. Appl Ergon. 2010;41:763-70.

30. Bovenzi M, Ronchese F, Mauro M. A longitudinal study of peripheral sensory function in vibrationexposed workers. Int Arch Occup Environ Health. 2011;84:325-34.

31. Tiemessen IJ, Hulshof CT, Frings-Dresen MH. The development of an intervention programme to reduce whole-body vibration exposure at work induced by a change in behaviour: a study protocol. BMC Public Health. 2007;7:329-39.
32. Howard B, Sesek R, Bloswick D. Typical whole body vibration exposure magnitudes encountered in the open pit mining industry. Work .2009;34:297-303.

33. Lis AM, Black KM, Korn H, Nordin M. Association between sitting and occupational LBP. Eur Spine. J 2007;16:283-298.

34. Dejours C. Psicopatología del trabajo - Psicodinámica del Trabajo. Laroreal. 2011; 7:13-6.

Recebido: $21 / 10 / 2014$

Received: 10/21/2014

Aprovado: 28/05/2015

Approved: 05/28/2015 